\title{
Blood metabolites and hormone-based programmed breeding treatments in anovular lactating dairy cows
}

\author{
S. Z. El-Zarkouny, ${ }^{\star 1}$ M. M. Shaaban, ${ }^{\star}$ and J. S. Stevenson† \\ *Department of Animal Production, Faculty of Agriculture, Alexandria University, Alexandria-21545, Egypt \\ †Department of Animal Sciences and Industry, Kansas State University, Manhattan 66506-0201
}

\begin{abstract}
The objectives were to (1) compare blood metabolites and reproductive outcomes in lactating dairy cows not inseminated before (early) and after (late) $100 \mathrm{~d}$ in milk (DIM) because of prolonged anovulation or anestrus; and (2) evaluate reproductive responses of cows $\leq 100 \mathrm{DIM}$ to $\mathrm{GnRH}+\mathrm{PGF}_{2 \alpha}$ treatments after a fixed-time artificial insemination (AI; Ovsynch) or after induced estrus (Select Synch). In blood samples collected before initiating hormone-based breeding programs, anovular cows $\leq 100$ DIM had the greatest serum total protein and globulin concentrations and the lowest tri-iodothyronine concentrations. Anovular and ovular cows $>100$ DIM had the greatest serum urea concentrations. Ovaries in cows $(\mathrm{n}=40)>100$ DIM were examined by transrectal ultrasonography, and those without a detectable corpus luteum (CL; anovular) were given $\mathrm{GnRH}$ and then $\mathrm{PGF}_{2 \alpha} 7 \mathrm{~d}$ later (Select Synch), whereas cows with a CL (ovular) were given $2 \mathrm{PGF}_{2 \alpha}$ injections $12 \mathrm{~d}$ apart. Cows were inseminated at observed estrus after the second or only $\mathrm{PGF}_{2 \alpha}$ injection. More ovular $(79 \% ; 15 / 19)$ than anovular cows $(24 \% ; 5 / 21)$ were detected in estrus. No differences were detected between ovular and anovular cows in DIM at first AI, conception rate to first AI, cumulative pregnancy rates, number of services per conception, or days open. Cows $(\mathrm{n}=93) \leq 100$ DIM were assigned randomly to 3 treatments: $(1)$ control $(\mathrm{n}=20) \mathrm{AI}$ at estrus; (2) GnRH and then PGF $_{2 \alpha}$ on $7 \mathrm{~d}$ (Select Synch; $\mathrm{n}=42$ ) and monitored for signs of estrus for $5 \mathrm{~d}$ and AI accordingly; or (3) $2 \mathrm{GnRH}$ injections $9 \mathrm{~d}$ apart with $\mathrm{PGF}_{2 \alpha}$ given $48 \mathrm{~h}$ before second $\mathrm{GnRH}$ injection and $\mathrm{AI}$ at $16 \mathrm{~h}$ after the second $\mathrm{GnRH}$ injection (Ovsynch; $\mathrm{n}$ $=31$ ). Among cows $\leq 100$ DIM, controls had more days to first service $(149 \pm 16$ d) than Select Synch cows $(117 \pm 7 \mathrm{~d})$. Ovsynch cows had the fewest days to first service $(84 \pm 10 \mathrm{~d})$ compared with control $(149 \pm 16 \mathrm{~d})$ and Select Synch $(117 \pm 7 \mathrm{~d})$ cows. Conception rates
\end{abstract}

Received April 8, 2011.

Accepted August 30, 2011.

${ }^{1}$ Corresponding author: elzarkouny@yahoo.com in control (25\%) and Select Synch (26.2\%) cows did not differ from those in Ovsynch cows (29\%). Ovsynch cows had greater cumulative pregnancy rates and fewer days open than control $(161 \pm 20$ vs. $258 \pm 29$ d), but did not differ from Select Synch $(233 \pm 19$ d). Timed AI produced comparable fertility and superior cumulative pregnancy rates, fewer days to first service, and fewer days open than AI at observed estrus in cows inseminated $\leq 100$ DIM.

Key words: anovulation, blood metabolite, hormonebased insemination

\section{INTRODUCTION}

Anestrus is a major contributor to infertility because a significant proportion of cows, ranging from 8 to $56 \%$ (El-Zarkouny et al., 2004; Silva et al., 2007), have not initiated ovulatory estrous cycles before an AI program is implemented. A major challenge for AI of dairy cows is the absence of estrus or such a subtle display of estrual symptoms that cows may not be detected in estrus for prolonged periods after calving. Therefore, DIM at first service and days open are extended.

Anovulation in lactating dairy cows may be associated with disease, low DMI, negative energy balance, and low body condition (Stevenson et al., 1997). Metabolic markers may provide some information about the causes and correlative effects of various factors associated with prolonged anovulation. Efficiency of reproduction is influenced by factors that affect the establishment of pregnancy, such as dietary protein (Elrod and Butler, 1993; Elrod et al., 1993), milk yield (Laben et al., 1982), and energy balance (Haresign, 1981). High protein diets can be detrimental to expression of estrus (Orihuela, 2000). Greater dietary protein intake will increase milk yield, which is not emulated entirely by energy intake, subsequently exacerbating negative energy balance. Negative energy balance will increase the risk of prolonged anestrus (Ferguson, 1991) resulting from reduced follicular development, which will reduce estradiol production and subsequent expression of estrus.

Anovular cows that were retrospectively identified after synchronization of ovulation and timed AI (TAI) 
had reduced fertility and greater pregnancy loss than their cycling herd mates (Sterry et al., 2006). Treatment of anovular cows with GnRH 5 d after TAI improved fertility for anovular cows but not for cycling cows. Strategies developed to resolve anovulation before or after TAI may be best achieved by identifying and targeting those anovular cows that may benefit from treatment rather than treating all cows (Silva et al., 2007). Cartmill et al. (2001) reported that $16.2 \%$ of cows were anovular by examining concentrations of progesterone in 3 blood samples collected before initiation of Ovsynch (2 GnRH injections $9 \mathrm{~d}$ apart with $\mathrm{PGF}_{2 \alpha}$ given $48 \mathrm{~h}$ before second $\mathrm{GnRH}$ injection and $\mathrm{AI}$ at $16 \mathrm{~h}$ after the second $\mathrm{GnRH}$ injection), whereas Gümen et al. (2003) used 2 consecutive weekly ultrasound examinations and blood samples to detect the presence of luteal tissue and serum progesterone and reported that $20.2 \%$ of cows were anovular.

Ovulation synchronization programs using only $\mathrm{PGF}_{2 \alpha}$ or combined with GnRH have been used widely to improve reproductive outcomes of dairy cows (Caraviello et al., 2006). Programs that regulate follicular development and luteal lifespan with sequential injections of $\mathrm{GnRH}$ and $\mathrm{PGF}_{2 \alpha}$ improve estrus detection rates and synchrony of estrus (Pursley et al., 1997).

To determine potential relationships between various blood metabolites and anovulation, the objectives were to (1) compare blood metabolite concentrations and reproductive outcomes in lactating dairy cows inseminated before (early) and after (late) 100 DIM; and (2) evaluate reproductive responses of cows $\leq 100$ DIM to $\mathrm{GnRH}+\mathrm{PGF}_{2 \alpha}$ treatments after a fixed-time AI (Ovsynch) or after induced estrus (Select Synch).

\section{MATERIALS AND METHODS}

\section{Cow Management}

The study was conducted in a dairy herd that consisted of 700 lactating Holstein cows in Egypt with an average daily milk yield of $25 \mathrm{~kg}$ per cow. Cows were housed in open barns with shades and machine-milked thrice daily. Cows were offered green artichoke $(7 \%$ of BW) from January to April, artichoke silage (3.5\% of BW) from May to June, chopped green corn (4\% of BW) from July to August, and corn silage (2\% of BW) and berseem (5\% of BW) from September to December. A concentrate mix $(16 \% \mathrm{CP})$ consisting of ground yellow corn, soybean meal, wheat bran, cottonseed cake, molasses, rumen-protected fat $(5 \%)$, and minerals (premix) was offered to cows every $6 \mathrm{~h}$ to meet or exceed NRC (1989) recommendations for lactating dairy cows. The total amount of the concentrate mix was $1 \mathrm{~kg}$ per
$2 \mathrm{~kg}$ of milk (3.5\% fat) or $2.5 \%$ of BW of cows. Cows had access to fresh water ad libitum.

\section{Synchronization of Estrus in Previously Noninseminated Cows with Extended Anovulation (>100 DIM)}

Transrectal ultrasound was implemented to identify anovulation in 40 cows having extended postpartum intervals $($ mean $=220 \pm 10$ and median $=193$ DIM) by subjecting them to one ovarian examination using a Dynamic Imaging scanner (Concept MLV, Livingston, UK) with a B-mode, real-time, 5.0- and 7.5-MHz dual probe. The $5.0-\mathrm{MHz}$ frequency feature of the probe was used to scan deeper structures such as uterine contents, whereas the $7.5-\mathrm{MHz}$ feature was used to scan ovaries when greater resolution was needed. Both ovaries were scanned to detect the number and diameter of the largest follicles, and number and diameter of each corpus luteum $(\mathbf{C L})$. Based on the presence of certain ovarian structures, cows were allotted to 2 treatments (Figure $1 \mathrm{~A}$ ). Select Synch (anovular, $\mathrm{n}=21$ ) cows were those having no CL present at the time of ovarian examination with or without a follicle $\geq 10 \mathrm{~mm}$ capable of ovulation in response to GnRH. Select Synch cows were treated with $8 \mu \mathrm{g}$ of buserelin ( $\mathrm{GnRH}$ analog; Receptal, Intervet International B.V., Boxmeer, Holland) followed in $7 \mathrm{~d}$ with $500 \mu \mathrm{g}$ of $\mathrm{PGF}_{2 \alpha}$ analog (Estrumate, Schering-Plough Animal Health, Friesoythe, Germany). Estrus was monitored closely twice daily for $1 \mathrm{~h}$ each for $5 \mathrm{~d}$ after $\mathrm{PGF}_{2 \alpha}$ injection. Detection of estrus was done visually in the morning and afternoon by herdsmen. No estrus detection aids were used. Cows detected in estrus in the morning were inseminated with frozenthawed semen in the evening of the same day and those detected in estrus in the evening were inseminated early the next morning. A second treatment $\left(2 \times \mathrm{PGF}_{2 \alpha}\right)$ was applied to the remaining cows having a CL (ovular; $\mathrm{n}=$ 19). These cows were given 2 injections of $\mathrm{PGF}_{2 \alpha} 12 \mathrm{~d}$ apart. Estrus was monitored closely twice daily for $1 \mathrm{~h}$ each for $5 \mathrm{~d}$ after each $\mathrm{PGF}_{2 \alpha}$ injection. Cows observed in estrus were inseminated using frozen-thawed semen. Cows exhibiting estrus and inseminated after the first $\mathrm{PGF}_{2 \alpha}$ injection did not receive the second $\mathrm{PGF}_{2 \alpha}$ injection. Body condition score $(1=$ emaciated and $5=$ obese; Wildman et al., 1982) was evaluated by the same individual at the time of enrollment.

\section{Synchronization of Ovulation or Estrus in Previously Noninseminated Cows ( $\leq 100$ DIM)}

Eight clusters of at least 10 lactating cows each $(\mathrm{n}=$ 93; mean and median $=64 \pm 2.3$ DIM) were assigned 


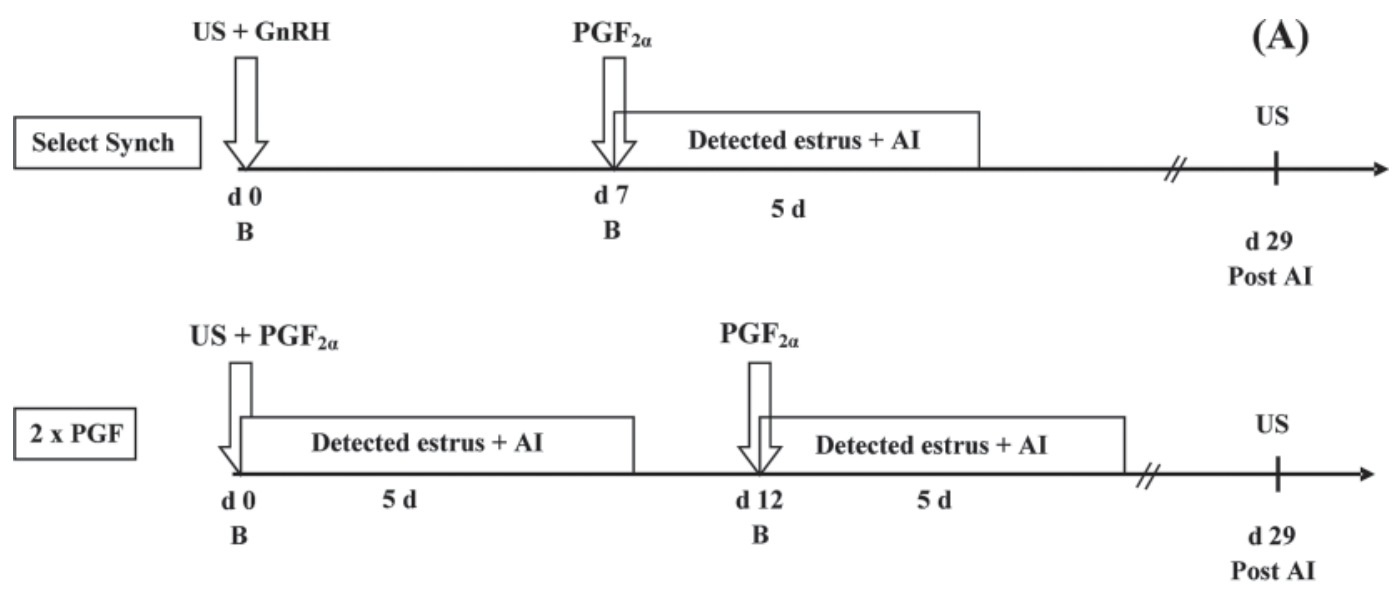

(B)
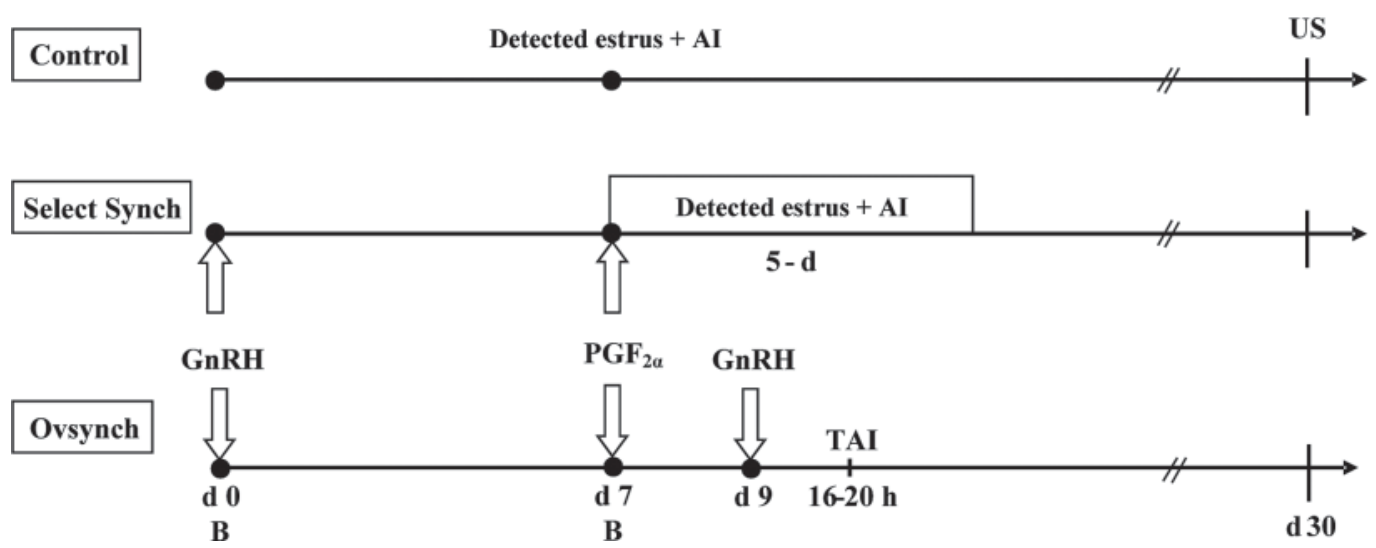

Figure 1. Synchronization of estrus or ovulation in dairy cows with (A) extended ( $\geq 100$ DIM; late) or (B) normal postpartum intervals to first service ( $\leq 100 \mathrm{DIM}$; early). Select Synch $=\mathrm{GnRH}-\mathrm{PGF}_{2 \alpha}$ (detection of estrus $\left.+\mathrm{AI}\right) ; 2 \times \mathrm{PGF}=\mathrm{PGF}_{2 \alpha}-\mathrm{PGF} 2 \alpha($ detection of estrus $+\mathrm{AI})$ $\mathrm{US}=$ ultrasound examination; $\mathrm{B}=$ blood sample; TAI $=$ timed AI.

randomly to 3 treatments based on BCS and lactation number at the time of enrollment (Figure 1B). Control cows $(\mathrm{n}=20)$ received no treatment, but were AI using frozen-thawed semen after daily detection of estrus. Select Synch cows $(\mathrm{n}=42)$ were administered $8 \mu \mathrm{g}$ of buserelin (GnRH analog; Receptal) followed in $7 \mathrm{~d}$ with $500 \mu \mathrm{g}$ of $\mathrm{PGF}_{2 \alpha}$ analog (Estrumate, Schering-Plough Animal Health). Cows were monitored closely for signs of behavioral estrus for $5 \mathrm{~d}$ and inseminated using frozen-thawed semen. Select Synch cows not detected in estrus received the same protocol $14 \mathrm{~d}$ later until inseminated. The third treatment (Ovsynch, $\mathrm{n}=32$ ) consisted of 2 injections of $8 \mu \mathrm{g}$ of buserelin (Receptal, Intervet International) $9 \mathrm{~d}$ apart plus 1 injection of 500 $\mu \mathrm{g}$ of $\mathrm{PGF}_{2 \alpha}$ analog (Estrumate, Schering-Plough Animal Health) given $48 \mathrm{~h}$ before the second injection of GnRH. Cows received a timed AI using frozen-thawed semen 16 to $20 \mathrm{~h}$ after the second injection of GnRH. The first GnRH injection was administered randomly without regard to stage of the estrous cycle or anovulation.

\section{Blood Collection}

Blood samples were collected via coccygeal venipuncture before each hormonal injection or at corresponding times from control cows (Figure 1). Blood samples were stored at $4^{\circ} \mathrm{C}$ for $12 \mathrm{~h}$ until serum was harvested after centrifugation $(1,935 \times g$ for $20 \mathrm{~min})$. Sera samples were stored at $-20^{\circ} \mathrm{C}$ until assayed. Concentrations of serum metabolites and tri-iodothyronine (T3) were measured in the first blood sample collected from each cow. Measurements of serum progesterone concentration were carried out in all blood samples.

\section{Biochemical Analysis of Serum Metabolites and Hormonal Assays}

Serum total protein, albumin, urea, glucose, total lipids, $\mathrm{Na}, \mathrm{K}$, and $\mathrm{P}$ were determined colorimetrically us- 
ing a visible light spectrophotometer (Pharmacia, LKB Biochrom, Cambridge, UK). All assays were carried out using commercial kits according the manufacturers' guidelines. Serum globulin was calculated by subtracting serum albumin concentrations from serum total protein concentrations.

An ELISA was used to measure serum concentrations of progesterone (Calbiotech Inc., Spring Valley, $\mathrm{CA}$ ). The lower limit of detection of progesterone was $0.3 \mathrm{ng} / \mathrm{mL}$. Intra- and inter-assay $\mathrm{CV}$ were 7.1 and $2.4 \%$, respectively. Progesterone concentrations $<1 \mathrm{ng} /$ $\mathrm{mL}$ in the first blood sample was used to classify earlyinseminated cows $\leq 100$ DIM into anovular or ovular $(\geq 1 \mathrm{ng} / \mathrm{mL})$ status. Concentrations of $\mathrm{T} 3$ in serum were measured using solid-phase enzyme immunoassay kits (Diatech Diagnostic Inc., Boston, MA). The lower limit of $\mathrm{T} 3$ detection $(95 \% \mathrm{~B} / \mathrm{Bo}$, where $\mathrm{B}=$ mean optical density of each pair of wells and Bo $=$ mean optical density of "0" standard wells) was $0.16 \mathrm{ng} / \mathrm{mL}$ and intra- and interassay CV were 6.4 and $5.1 \%$, respectively.

\section{Reproductive Outcomes}

Pregnancy was diagnosed by transrectal ultrasonography 29 to $30 \mathrm{~d}$ after AI and later confirmed by transrectal palpation of the uterus and its contents 40 to $50 \mathrm{~d}$ after AI by the herd veterinary practitioner. Cows that returned to estrus were reinseminated accordingly.

Reproductive outcomes included DIM at first service, conception rate to first AI, cumulative pregnancy rate (PR), number of services per conception, and days open. Days to first service was the difference between calving and the first AI date; $\mathbf{C R} / \mathbf{A I}=$ proportion of cows pregnant divided by the number of cows inseminated; PR $=$ proportion of cows pregnant divided by the number of cows enrolled in the study; and days open = interval between calving and confirmed pregnancy.

\section{Statistical Analyses}

Data for serum total protein, albumin, globulin, urea, glucose, total lipids, Na, K, P, and T3 were analyzed in separate linear models (procedure GLM; SAS Inst. Inc., Cary, NC) with ovarian status (anovular vs. ovular) and DIM ( $\leq 100$ vs. $>100)$ as main effects. Other variables (BCS, lactation number, and milk yield) and treatment by lactation number interactions were included in the model. To determine relationships among metabolites and conception status, pregnancy status was included in subsequent models.

Proportion of cows $>100$ DIM displaying estrus after $\mathrm{PGF}_{2 \alpha}$ treatment was analyzed by using $\chi^{2}$ (SAS Inst. Inc.) and the Fisher exact option with lactation num- ber (first- vs. multiple-lactation cows), BCS ( $<2.5$ vs. $\geq 2.5$ ), and daily milk yield ( $<25$ vs. $\geq 25 \mathrm{~kg}$ ), and their interaction with treatment included in the model.

Multivariate logistical regression models (procedure LOGISTIC, SAS Inst. Inc.) were developed to analyze the effects of hormone treatments (Select Synch and 2 $\times \mathrm{PGF}_{2 \alpha}$ in cows $>100$ DIM and control, Select Synch, and Ovsynch in cows $\leq 100$ DIM), lactation (first- vs. multiple-lactation cows), BCS ( $<2.5$ vs. $\geq 2.5$ ), and daily milk yield ( $<25$ vs. $\geq 25 \mathrm{~kg}$ ) on categorical outcome variables (CR/AI and overall $\mathrm{PR}$ ). All multivariate logistical regression models were constructed using a backward selection procedure with treatment retained as a fixed effect in each model. A Wald statistic criterion of $P<0.15$ was set for including variables in the model. Odds ratios (OR) and 95\% CI were calculated for significant and nonsignificant factors remaining in the final models. Results presented are percentages and proportions with $P$-values for main effects derived from the multivariate logistical regression analysis.

Days in milk at first service, number of services per conception, and days open were analyzed by ANOVA (procedure GLM; SAS Inst. Inc.) with Select Synch and $2 \times \mathrm{PGF}_{2 \alpha}$ treatments (cows $>100$ DIM) or control, Select Synch, and Ovsynch treatments (cows $\leq 100$ DIM) plus BCS, lactation number, daily milk yield, and interactions with treatments included in the model as described previously.

Progesterone concentrations in the second blood sample were analyzed by ANOVA (procedure GLM; SAS Inst. Inc.) with Select Synch and $2 \times \mathrm{PGF}_{2 \alpha}$ (cows $>100$ DIM) and control, Select Synch, and Ovsynch (cows $\leq 100$ DIM) treatments, plus BCS, lactation number, and daily milk yield, and their interactions with treatment included in the model.

Differences among least squares means were detected by the method of least-significant difference only when $F$-tests were significant $(P \leq 0.05)$ in the ANOVA.

\section{RESULTS}

\section{Blood Biochemical Traits}

Serum concentrations of total protein, albumin, globulin, urea, T3, total lipids, glucose, Na, K, and P in cows before hormone-based breeding treatments are illustrated in Figure 2 based on their ovulatory status and stage of lactation.

Total Protein. Early anovular cows ( $\leq 100$ DIM) had greater $(P<0.01)$ serum total protein concentrations $(11.6 \pm 0.9 \mathrm{~g} / \mathrm{dL})$ compared with late $(>100$ DIM) anovular and ovular cows and early ovular cows $(8.7 \pm 0.5,7.6 \pm 0.3$, and $8.5 \pm 0.3 \mathrm{~g} / \mathrm{dL}$, respectively $)$ 
First-lactation cows had greater $(P<0.05)$ serum total protein $(9.5 \pm 0.5)$ than multiple lactation cows $(8.4 \pm$ $0.4 \mathrm{~g} / \mathrm{dL})$.

Albumin. Late anovular cows had lesser $(P<0.01)$ serum albumin concentrations $(3.6 \pm 0.3 \mathrm{~g} / \mathrm{dL})$ than early anovular $(5.0 \pm 0.4 \mathrm{~g} / \mathrm{dL})$ and early ovular $(4.6$ $\pm 0.2 \mathrm{~g} / \mathrm{dL})$ cows. Serum globulin concentrations were greater $(P<0.01)$ in early anovular cows $(6.6 \pm 0.8$ $\mathrm{g} / \mathrm{dL})$ than in early ovular $(3.9 \pm 0.3 \mathrm{~g} / \mathrm{dL})$ cows and late anovular $(5.1 \pm 0.6 \mathrm{~g} / \mathrm{dL})$ and late ovular $(3.5 \pm$ $0.2 \mathrm{~g} / \mathrm{dL})$ cows.

Urea. Late (anovular and ovular) cows had greater $(P<0.01)$ serum urea concentrations $(43.5 \pm 2.5$ and $39.2 \pm 3.2 \mathrm{mg} / \mathrm{dL}$ ) than early (anovular and ovular) cows $(28.5 \pm 1.8$ and $31.7 \pm 1.1 \mathrm{mg} / \mathrm{dL})$. Late cows with low $(<2.5, \mathrm{n}=28)$ BCS had greater $(P<0.05)$ serum urea concentration $(44.6 \pm 2.2 \mathrm{mg} / \mathrm{dL})$ than late cows with higher $(\geq 2.5, \mathrm{n}=12) \mathrm{BCS}(34.0 \pm 3.6 \mathrm{mg} /$ $\mathrm{dL})$ and early cows either with low $(<2.5)$ BCS $(31.0 \pm$ $1.1 \mathrm{mg} / \mathrm{dL})$ or higher $(\geq 2.5)$ BCS $(31.4 \pm 1.9 \mathrm{mg} / \mathrm{dL})$. Cows that conceived to first AI had lower $(P<0.01)$ serum urea concentrations $(29.4 \pm 2.8 \mathrm{mg} / \mathrm{dL})$ than those failed to conceive to first AI $(37.9 \pm 1.4 \mathrm{mg} / \mathrm{dL})$.

T3. Early anovular cows had lower $(P<0.05)$ serum T3 concentrations $(2.5 \pm 0.2 \mathrm{ng} / \mathrm{mL})$ than early ovular $(4.2 \pm 0.3 \mathrm{ng} / \mathrm{mL})$ and late anovular $(4.1 \pm 0.3)$ and late ovular $(4.0 \pm 0.4 \mathrm{ng} / \mathrm{mL})$ cows.

Total Lipid. Late ovular cows had lower $(P<0.05)$ serum total lipid concentration $(738 \pm 46 \mathrm{mg} / \mathrm{dL})$ than late anovular $(897 \pm 36 \mathrm{mg} / \mathrm{dL})$ and early ovular $(987$ $\pm 35 \mathrm{mg} / \mathrm{dL}$ ) cows, but did not differ from early anovular $(849 \pm 43)$ cows.

Potassium. Late anovular cows had greater $(P<$ $0.01)$ serum $K$ concentrations $(7.5 \pm 0.1 \mathrm{mmol} / \mathrm{L})$ than late ovular $(5.6 \pm 0.2 \mathrm{mmol} / \mathrm{L})$ cows. Serum K concentration in early anovular $(6.4 \pm 0.5 \mathrm{mmol} / \mathrm{L})$ cows did not differ from that in early ovular cows $(6.6 \pm$ $0.3 \mathrm{mmol} / \mathrm{L}$ ), but remained different from that in late ovular cows $(5.6 \pm 0.2 \mathrm{mmol} / \mathrm{L})$. First-lactation cows had greater $(P<0.05)$ serum $\mathrm{K}$ concentrations $(7.0 \pm$ $0.1)$ than older cows $(6.4 \pm 0.2 \mathrm{mmol} / \mathrm{L})$. In addition, cows that conceived at first AI service had greater $(P$ $<0.05)$ serum $\mathrm{K}$ concentrations than those cows that failed to conceive $(7.0 \pm 0.3$ vs. $6.4 \pm 0.2 \mathrm{mmol} / \mathrm{L})$.

Other Metabolites. No differences were detected in serum glucose, $\mathrm{Na}$, or $\mathrm{P}$ concentrations among cycling statuses and stages of lactation.

\section{Reproductive Outcomes}

Serum Progesterone. Ovarian scans revealed that $55 \%(21 / 40)$ of late cows (>100 DIM) were anovular (no detectable CL), but had $3.5 \pm 0.5$ follicles $\geq 10 \mathrm{~mm}$. Average diameter of the largest follicle was $12.5 \pm 1.2$ $\mathrm{mm}$. The remaining $45 \%(19 / 40)$ of late cows $(>100$ DIM) were ovular (had detectable luteal structures; 1.3 $\pm 0.2 \mathrm{CL} /$ cow with a diameter of $19.4 \pm 2.1 \mathrm{~mm})$. Anovular cows had lower $(P<0.05)$ serum concentrations of progesterone $(1.7 \pm 0.1 \mathrm{ng} / \mathrm{mL})$ at the time of the GnRH injection than ovular cows $(4.9 \pm 0.5 \mathrm{ng} / \mathrm{mL})$. Ovular cows had a greater $(P<0.01)$ estrus detection rate $(79 \% ; 15 / 19)$ than anovular cows $(24 \% ; 5 / 21)$ after $\mathrm{PGF}_{2 \alpha}$.

Before the GnRH injection (Select Synch or Ovsynch), all early cows ( $\leq 100$ DIM) had similar serum concentrations of progesterone. At the time of $\mathrm{PGF}_{2 \alpha}$ injection ( $7 \mathrm{~d}$ after first GnRH injection), cows treated with Ovsynch and Select Synch had greater $(P<0.01)$ progesterone $(4.2 \pm 0.5 \mathrm{ng} / \mathrm{mL})$ than controls $(2.8 \pm$ $0.5 \mathrm{ng} / \mathrm{mL})$.

Fertility Traits. All late-AI cows had low CR/AI whether they were anovular (Select Synch) or ovular $\left(2 \times \mathrm{PGF}_{2 \alpha}\right.$, Table 1$)$. Further, among early cows inseminated after detected estrus (Select Synch) or by appointment, CR/AI did not differ (Table 1). Fewer $(P$ $=0.049 ; \mathrm{OR}=0.34,95 \% \mathrm{CI}=0.11$ to 0.99$)$ early inseminated cows with BCS $<2.5$ conceived $(21 \% ; 11 / 54)$ than cows having $\mathrm{BCS} \geq 2.5(35 \% ; 14 / 40)$. In addition, more $(P=0.023$; OR $=4.13 ; 95 \% \mathrm{CI}=1.22$ to 14.01 ; $37.5 \%, 12 / 32)$ early inseminated, first-lactation cows conceived at first AI compared with multiple-lactation cows $(21.3 \%, 13 / 61)$.

Late inseminated ovular $\left(2 \times \mathrm{PGF}_{2 \alpha}\right)$ and anovular (Select Synch) cows had similar cumulative PR at the end of the 120-d breeding period (Table 2). In contrast, PR in early inseminated cows after observed estrus (Select Synch and control) did not differ, whereas Ovsynch-treated cows had greater PR than controls inseminated after observed estrus.

Early and late inseminated cows had similar cumulative PR (Table 2). Early cows having milk yield $<25 \mathrm{~kg}$ $(21.1 \pm 0.5 \mathrm{~kg})$ tended $(P=0.08 ; \mathrm{OR}=0.28,95 \% \mathrm{CI}$ $=0.07$ to 1.17 ) to have lower PR than cows producing $\geq 25 \mathrm{~kg}(32.3 \pm 0.5 \mathrm{~kg})$ of milk.

No difference in days to first service was detected between Select Synch (anovular) and $2 \times \mathrm{PGF}_{2 \alpha}$ (ovular) cows after treatment (Table 3). Late cows with low milk yield $(<25 \mathrm{~kg} / \mathrm{d})$ had more $(P<0.01)$ days to first service $(276 \pm 19 \mathrm{~d})$ than cows with greater milk yield ( $\geq 25 \mathrm{~kg} / \mathrm{d} ; 198 \pm 23 \mathrm{~d})$. Early control cows inseminated at observed estrus had more $(P<0.01)$ days to first service than cows that received the Select Synch protocol (Table 3). Ovsynch cows had the fewest $(P<0.01)$ days to first service.

Number of services per conception did not differ for any of the comparisons examined (Table 3). Days open did not differ in late cows, but early cows that received the Ovsynch protocol had fewer $(P<0.01)$ days open 

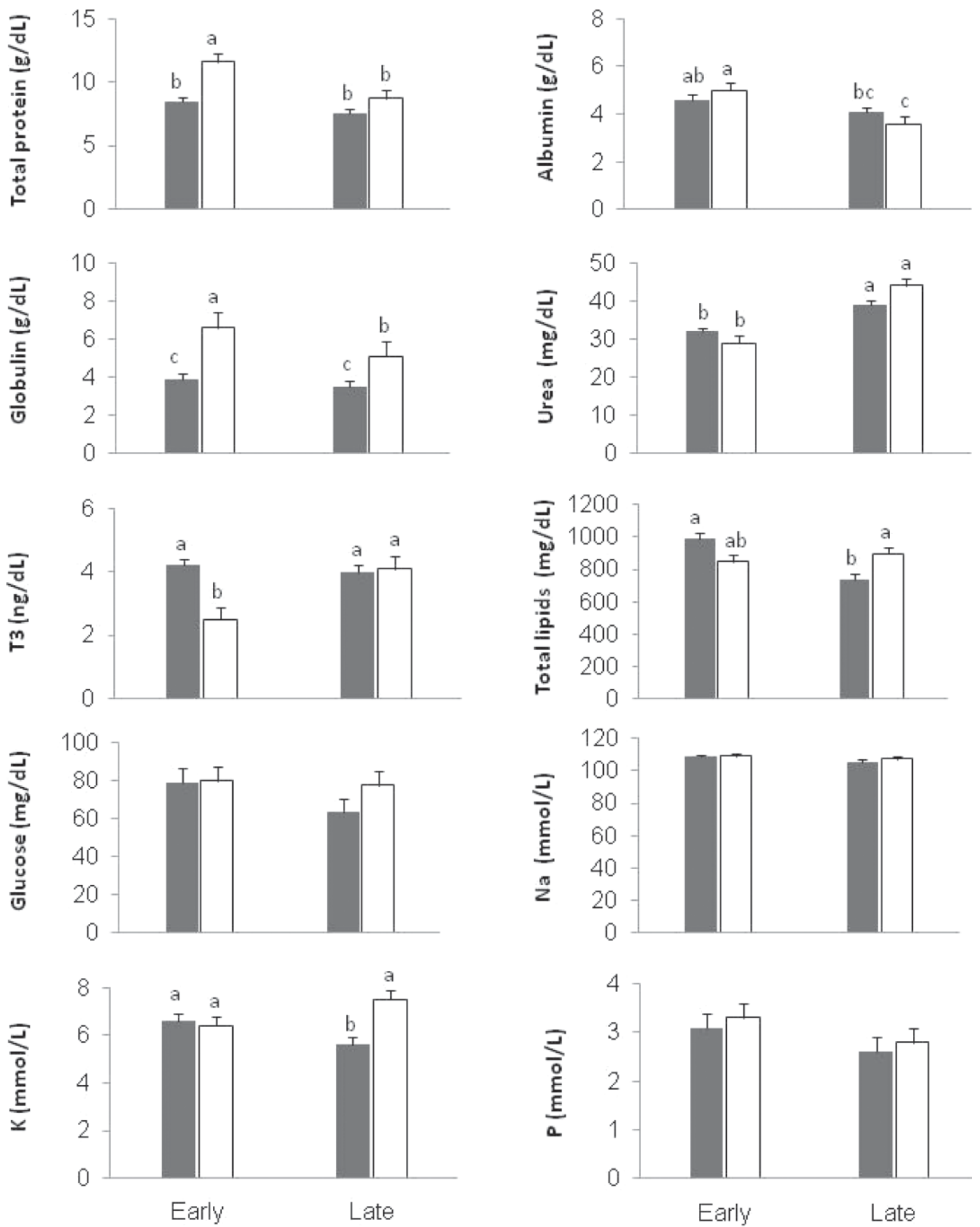

Figure 2. Serum concentrations of total protein, albumin, globulin, urea, tri-iodothyronine (T3), total lipids, glucose, Na, K, and P in early $(\leq 100$ DIM; median $=64)$ and late $(>100$ DIM; median $=193)$ lactating dairy cows depending on ovular (solid bars) or anovular (open bars) status before treatment with hormone-based protocols. ${ }^{a-c}$ Mean concentrations within measure having different letters differ $(P \leq 0.05)$. 
Table 1. Conception rates in late and early postpartum dairy cows after synchronization of ovulation or estrus with GnRH and PGF-based programs

\begin{tabular}{llcccc}
\hline DIM & Treatment & $\begin{array}{c}\text { Conception rate, } \\
\%(\text { no. } / \text { no. })\end{array}$ & $\begin{array}{c}\text { Odds } \\
\text { ratio }\end{array}$ & $\begin{array}{c}95 \% \\
\text { CI }\end{array}$ & $P$-value \\
\hline Late $^{2}$ & $2 \times \mathrm{PGF}_{2 \alpha}$ & $21.0(4 / 19)$ & Referent & & \\
& Select Synch & $9.5(2 / 21)$ & 0.33 & $0.05-2.26$ & 0.259 \\
Early $^{3}$ & & $25.0(5 / 20)$ & Referent & & \\
& Control & $26.2(11 / 42)$ & 1.47 & $0.38-5.59$ & 0.576 \\
Overall & Select Synch & $29.0(9 / 31)$ & 1.72 & $0.42-7.04$ & 0.452 \\
Late & Ovsynch & $15.0(6 / 40)$ & Referent & & \\
Early & & $27.9(25 / 93)$ & 2.08 & $0.78-5.56$ & 0.143 \\
\hline
\end{tabular}

${ }^{1}$ Odds ratio is function of estimated probability of pregnancy. Ratios exceeding 1 indicate increased probability of pregnancy, whereas ratios less than 1 indicate decreased probability of pregnancy.

${ }^{2}$ Late $=$ cows not detected in estrus during first $100 \mathrm{DIM} ; 2 \times \mathrm{PGF}_{2 \alpha}=$ corpus luteum was present (ovular) and cows were treated with $\mathrm{PGF}_{2 \alpha} 12 \mathrm{~d}$ apart. Select Synch $=$ No CL present (anovular) and cows received GnRH injection followed with $\mathrm{PGF}_{2 \alpha}$ injection $7 \mathrm{~d}$ later.

${ }^{3}$ Early $=$ cows assigned to breeding clusters before 100 DIM. Control = detection of estrus + AI; Select Synch

$=\mathrm{GnRH}$ injection $7 \mathrm{~d}$ before $\mathrm{PGF}_{2 \alpha}$; Ovsynch $=\mathrm{GnRH}$ injection $7 \mathrm{~d}$ before and $48 \mathrm{~h}$ after $\mathrm{PGF}_{2 \alpha}$, with timed

$\mathrm{AI}$ administered 16 to $20 \mathrm{~h}$ after the second GnRH injection.

than controls and Select Synch cows. Early cows with higher BCS $(\geq 2.5)$ had fewer $(P<0.05)$ days open $(183 \pm 19 \mathrm{~d})$ than cows having low BCS $(<2.5 ; 237 \pm$ $18 \mathrm{~d})$.

\section{DISCUSSION}

Altered serum concentrations of total protein, globulin, and albumin and increased blood urea (observed in all cows >100 DIM) may indicate some liver impairment that is associated with prolonged anovulation and low fertility. An excessive intake of protein may cause ruminal alkalosis and increased rumen ammonia, resulting in energy deficits and disorders of hepatocytes (Sommer, 1975).
Excess degradable (Elrod and Butler, 1993) or undegradable protein (Elrod et al., 1993) contributed to decreased uterine $\mathrm{pH}$ during the luteal phase, which might be involved in the observed reduction in fertility. Dairy cows are commonly fed diets containing large amounts of CP to maximize milk production (Rhoads et al., 2006). As a consequence of increased CP in their diets, lactating dairy cows have increased plasma urea nitrogen associated with decreased fertility (Ferguson, 1991; Butler et al., 1996).

In the present study, multiple-lactation anestrous cows $($ milk yield $=27 \mathrm{~kg} / \mathrm{d}$ ) or those with low BCS had greater blood urea concentrations compared with first-lactation cows (milk yield $=21 \mathrm{~kg} / \mathrm{d}$ ) and cows with high BCS (data not shown). Increased blood urea

Table 2. Total pregnancy rates in late and early postpartum cyclic dairy cows after synchronization with GnRH and PGF-based programs

\begin{tabular}{|c|c|c|c|c|c|}
\hline DIM & Treatment & $\begin{array}{c}\text { Cumulative } \\
\text { pregnancy rate, } \\
\% \text { (no./no.) }\end{array}$ & $\begin{array}{l}\text { Odds } \\
\text { ratio }^{1}\end{array}$ & $\begin{array}{c}95 \% \\
\text { CI }\end{array}$ & $P$-value \\
\hline$\overline{\text { Late }^{2}}$ & $\begin{array}{l}2 \times \mathrm{PGF}_{2 \alpha} \\
\text { Select Synch }\end{array}$ & $\begin{array}{l}73.6(14 / 19) \\
76.2(16 / 21)\end{array}$ & $\begin{array}{c}\text { Referent } \\
1.16\end{array}$ & $0.23-5.81$ & 0.857 \\
\hline Early $^{3}$ & $\begin{array}{l}\text { Control } \\
\text { Select Synch } \\
\text { Ovsynch }\end{array}$ & $\begin{array}{l}70.0(14 / 20) \\
85.7(36 / 42) \\
93.5(29 / 31)\end{array}$ & $\begin{array}{c}\text { Referent } \\
3.19 \\
7.54\end{array}$ & $\begin{array}{l}0.81-12.53 \\
1.22-46.49\end{array}$ & $\begin{array}{l}0.096 \\
0.029\end{array}$ \\
\hline $\begin{array}{l}\text { Overall } \\
\text { Late } \\
\text { Early }\end{array}$ & & $\begin{array}{l}75.0(30 / 40) \\
84.9(79 / 93)\end{array}$ & $\begin{array}{c}\text { Referent } \\
1.88\end{array}$ & $0.75-4.69$ & 0.175 \\
\hline \multicolumn{6}{|c|}{ 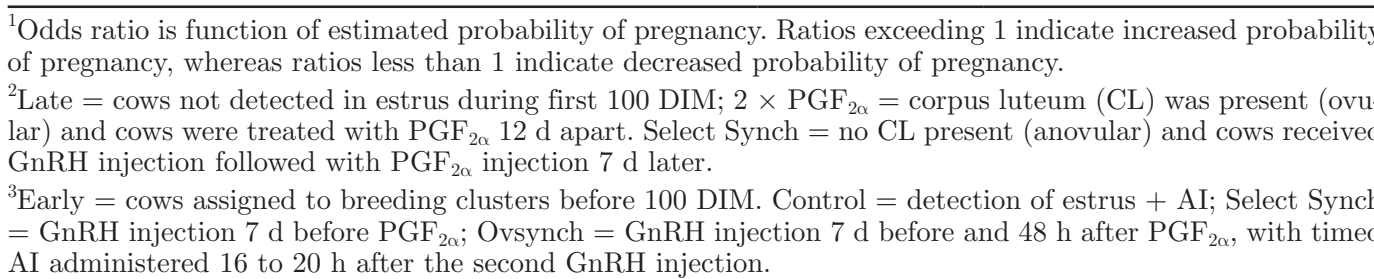 } \\
\hline
\end{tabular}


Table 3. Days in milk at first service, services per conception, and days open in late ( $>100$ DIM) and early ( $\leq 100$ DIM) postpartum dairy cows after synchronization of estrus or ovulation with hormone-based programs

\begin{tabular}{llcccc}
\hline DIM & Treatment & $\mathrm{n}$ & $\begin{array}{c}\text { Days to } \\
\text { first service }\end{array}$ & $\begin{array}{c}\text { Services } \\
\text { per conception }\end{array}$ & $\begin{array}{c}\text { Days } \\
\text { open }\end{array}$ \\
\hline Late $^{1}$ & $2 \times \mathrm{PGF}_{2 \alpha}$ & 19 & $277 \pm 25$ & $2.5 \pm 0.4$ & $345 \pm 25$ \\
& Select Synch & 21 & $239 \pm 21$ & $2.6 \pm 0.4$ & $341 \pm 26$ \\
Early $^{2}$ & & & & & \\
& Control & 20 & $149 \pm 16^{\mathrm{a}}$ & $2.6 \pm 0.5$ & $258 \pm 29^{\mathrm{a}}$ \\
& Select Synch & 42 & $117 \pm 7^{\mathrm{b}}$ & $3.4 \pm 0.4$ & $233 \pm 19^{\mathrm{a}}$ \\
Overall & Ovsynch & 31 & $84 \pm 10^{\mathrm{c}}$ & $2.0 \pm 0.5$ & $161 \pm 20^{\mathrm{b}}$ \\
Late & & & & \\
Early & & & $257 \pm 16^{\mathrm{d}}$ & $2.6 \pm 0.4$ & $343 \pm 18^{\mathrm{c}}$ \\
\hline
\end{tabular}

${ }^{\mathrm{a}, \mathrm{b}}$ Means within DIM group having different superscript letters differ $(P<0.01)$.

${ }^{\mathrm{c}, \mathrm{d}}$ Overall means within column having different superscript letters differ $(P<0.01)$.

${ }^{1}$ Late $=$ cows not detected in estrus during first 100 DIM; $2 \times \mathrm{PGF}_{2 \alpha}=$ corpus luteum $(\mathrm{CL})$ was present (ovular) and cows were treated with $\mathrm{PGF}_{2 \alpha} 12 \mathrm{~d}$ apart. Select Synch = no CL present (anovular) and cows received GnRH injection followed with $\mathrm{PGF}_{2 \alpha}$ injection $7 \mathrm{~d}$ later.

${ }^{2}$ Early $=$ cows assigned to breeding clusters before 100 DIM. Control = detection of estrus + AI; Select Synch $=\mathrm{GnRH}$ injection $7 \mathrm{~d}$ before $\mathrm{PGF}_{2 \alpha} ;$ Ovsynch $=\mathrm{GnRH}$ injection $7 \mathrm{~d}$ before and $48 \mathrm{~h}$ after $\mathrm{PGF}_{2 \alpha}$, with timed AI administered 16 to $20 \mathrm{~h}$ after the second GnRH injection.

concentrations in anestrous cows of low body condition $(<2.5)$ might have contributed to the increased days to first AI and more days open compared with early inseminated cows.

Consistent with our observations of decreased serum albumin in late anovular cows, albumin concentration was significantly decreased in cows with moderate and severe fatty liver compared with controls and cows having mild fatty livers (Sevinc et al., 2003).

A significant relationship between increasing concentrations of $\mathrm{T} 3$ or thyroid hormone and fertility provides evidence that thyroid hormones are metabolic signals that trigger the onset of ovarian cycles (Reist et al., 2003). Thyroid hormones have stimulatory effects on ovarian function in cattle acting at the level of granulosa and theca cells (Spicer et al., 2001). The finding of reduced serum T3 concentrations in anovular cows $\leq 100$ DIM in the current study supports these studies.

Proportions of late ovular (45\%) and anovular (55\%) cows >100 DIM were similar in the current herd and these cows were classified as anestrous based on the absence of detected estrus (Rhodes et al., 2003). A short period of elevated progesterone concentration during the postpartum period resulting from endogenous or exogenous sources is important for subsequent expression of estrus and normal luteal function (McDougall et al., 1992). Therefore, the percentage of anovular cows displaying estrus after $\mathrm{PGF}_{2 \alpha}$ treatment was low compared with their ovular herd mates that had a detectable CL from a previous ovulation and were exposed to endogenous progesterone.

Smaller follicles found in anovular cows produced meager CL after GnRH treatment and resulted in reduced progesterone concentrations. Follicles $<10 \mathrm{~mm}$ resulted in reduced ovulation risk to GnRH (Sterry et al., 2009). The low response to $\mathrm{GnRH}$ treatment might be explained on the basis that follicles cannot be classified as either normal or atretic by an ultrasound examination. Further, the average diameter of the largest follicle was $12.5 \mathrm{~mm}$ in the current study, which is less than the size of normal ovulatory follicles (Vasconcelos et al., 1999). Based on follicular diameter, these cows would have fit the first category of anovulatory follicles (deviation to ovular size of 9 to $14 \mathrm{~mm}$ in diameter) as classified by Wiltbank et al. (2002).

In both low- and high-yielding dairy cows, an economic benefit is associated with reducing the number of cows with extended intervals from calving to conception (Esslemont et al., 2001). Traditionally, treatment of cows that have not been detected in estrus but have a detectable CL has focused on the use of $\mathrm{PGF}_{2 \alpha}$ (Rhodes et al., 2003). Within $6 \mathrm{~d}$ of treatment with $\mathrm{PGF}_{2 \alpha}, 55 \%$ of cows with an ultrasonographically detectable CL were detected in estrus (Smith et al., 1998). When a CL was detected following ovarian palpation, estrousresponse rates within $6 \mathrm{~d}$ of treatment averaged $52 \%$ and ranged from 36 to $68 \%$, with the majority of cows displaying estrus within $4 \mathrm{~d}$ of treatment (Plunkett et al., 1984; Whittier et al., 1989). These results demonstrate that the estrous response to $\mathrm{PGF}_{2 \alpha}$ treatment in this class of cows (anestrous with detectable CL) is not great compared with that observed in cows that resumed earlier estrous cycles, where 63 to $88 \%$ of cows were detected in estrus within $7 \mathrm{~d}$ of $\mathrm{PGF}_{2 \alpha}$ treatment (Xu et al., 1997).

Conception rate following $\mathrm{GnRH}+\mathrm{PGF}_{2 \alpha}$ treatment and estrus detection + AI in the current study (9.5\%) was comparable with that in anovular cows following 
Ovsynch (9\%; Gümen et al., 2003) or comparable with other reports from 24 to $37 \%$ in anovular cows after Ovsynch (Fricke and Wiltbank, 1999; Bartolome et al., 2000). An explanation for reduced CR/AI in anovular cows was the reportedly greater rate of post-AI premature luteal regression (23 vs. $6 \%$ ) in anovular compared with ovular cows (Gümen et al., 2003).

Extended days open may have occurred because of impaired metabolic functions that resulted in increased serum urea and decreased albumin concentration in cows $>100$ DIM. Ovular cows had fewer days open (120 d) than anovular cows (150 d; Gümen et al., 2003). Ultrasound scanning started earlier (47 to 60 DIM) in the previous study compared with $\geq 100$ DIM in the current study. In addition, DIM at first breeding was $256 \mathrm{~d}$ in our study, resulting in increased days open beyond what was reported earlier (Gümen et al., 2003).

Ovsynch treatment reduced days to first AI (54 vs. 83 d) compared with controls (Pursley et al., 1997). In the same study, days to second and third AI were also reduced. Conception rates to first AI were similar for control and Ovsynch, although Ovsynch cows were inseminated $19 \mathrm{~d}$ sooner. Our results support these previous reports where our cows inseminated after detected estrus (controls and Select Synch) and inseminated at fixed TAI (Ovsynch) had similar CR/AI. Our cumulative $\mathrm{PR}$ at the end of breeding period supports previous results (Pursley et al., 1997) where our Ovsynch and Select Synch cows had greater PR than controls. The cumulative PR in the present study was greater than that in other studies (Mialot et al., 1999; McDougall, 2001), where PR in Ovsynch cows were 36 and 58\%, respectively. Disadvantages of AI after detected estrus (control and Select Synch) were the lower estrus detection rates compared with AI submission rates (100\%) after Ovsynch and that the incidence of ovulation may be less after the $\mathrm{PGF}_{2 \alpha}$ injection compared with the second $\mathrm{GnRH}$ injection given $48 \mathrm{~h}$ after the $\mathrm{PGF}_{2 \alpha}$ injection in the Ovsynch program.

\section{CONCLUSIONS}

Extended postpartum intervals were associated with management omission of detected estrus in ovular cows and biochemical differences, including elevated concentrations of blood urea and reduced concentrations of albumin. Furthermore, all anovular cows regardless of stage of lactation had greater serum globulin than their ovular herd mates. Delayed synchronization treatment and reduced detection of estrus contributed to extended postpartum intervals to first AI and increased days open. More attention should be addressed to diet composition (degradable and undegradable protein), DMI, and BCS during the transition period. In addi- tion, prolonged anestrus may be circumvented before AI by applying GnRH + PGF-based treatments that induce ovulation and produce suitable pregnancy rates. In early postpartum cows, TAI produced comparable $\mathrm{CR} / \mathrm{AI}$ to first AI and superior PR, fewer DIM at first AI, and fewer days open than AI after observed estrus. Reduced fertility at first AI was associated with lower serum K, low BCS, and elevated serum urea concentration.

\section{REFERENCES}

Bartolome, J. A., L. F. Archbald, P. Morresey, J. Hernandez, T. Tran, D. Kelbert, K. Long, C. A. Risco, and W. W. Thatcher. 2000. Comparison of synchronization of ovulation and induction of estrus as therapeutic strategies for bovine ovarian cysts in the dairy cow. Theriogenology 53:815-825.

Butler, W. R., J. J. Calaman, and S. W. Beam. 1996. Plasma and milk urea nitrogen in relation to pregnancy rate in lactating dairy cattle. J. Anim. Sci. 74:858-865.

Caraviello, D. Z., K. A. Weigel, P. M. Fricke, M. C. Wiltbank, M. J. Florent, N. B. Cook, K. V. Nordlund, N. R. Zwald, and C. L. Rawson. 2006. Survey of management practices on reproductive performance of dairy cattle on large US commercial farms. J. Dairy Sci. 89:4723-4735.

Cartmill, J. A., S. Z. El-Zarkouny, B. A. Hensley, G. C. Lamb, and J. S. Stevenson. 2001. Stage of cycle, incidence, and timing of ovulation, and pregnancy rates in dairy cattle after three timed breeding protocols. J. Dairy Sci. 84:1051-1059.

El-Zarkouny, S. Z., J. A. Cartmill, B. A. Hensley, and J. S. Stevenson. 2004. Pregnancy in dairy cows after synchronized ovulation regimens with or without presynchronization and progesterone. J. Dairy Sci. 87:1024-1037.

Elrod, C. C., and W. R. Butler. 1993. Reduction of fertility and alteration of $\mathrm{pH}$ in heifers fed excess ruminally degradable protein. J. Anim. Sci. 71:694-701.

Elrod, C. C., M. Van Amburgh, and W. R. Butler. 1993. Alterations of $\mathrm{pH}$ in response to increased dietary protein in cattle are unique to the uterus. J. Anim. Sci. 71:702-706.

Esslemont, R. J., M. A. Kossaibati, and J. Allcock. 2001. Economics of fertility in dairy cows. Pages 19-29 in Fertility in the High Producing Dairy Cow. Occ. Pub. 26. M. G. Diskin, ed. Br. Soc. Anim. Sci., Edinburgh, UK.

Ferguson, J. D. 1991. Nutrition and reproduction in dairy cows. Vet. Clin. North Am. Food Anim. Pract. 7:483-507.

Fricke, P. M., and M. C. Wiltbank. 1999. Effect of milk production on the incidence of double ovulation in dairy cows. Theriogenology 52:1133-1143.

Gümen, A., J. N. Guenther, and M. C. Wiltbank. 2003. Follicular size and response to Ovsynch versus detection of estrus in anovular and ovular lactating dairy cows. J. Dairy Sci. 86:3184-3194.

Haresign, W. 1981. Body condition, milk yield and reproduction. Pages 1-16 in Recent Developments in Ruminant Nutrition. W. Haresign and D. J. A. Cole, ed. Butterworths, London, UK.

Laben, R. L., R. D. Shanks, P. J. Berger, and A. E. Freeman. 1982. Factors affecting milk yield and reproductive performance. J. Dairy Sci. 65:1004-1015.

McDougall, S. 2001. Reproductive performance of anovulatory anoestrous postpartum dairy cows following treatment with two progesterone and oestradiol benzoate-based protocols, with or without resynchrony. N.Z. Vet. J. 49:187-194.

McDougall, S., C. R. Burke, K. L. Macmillan, and N. B. Williamson. 1992. The effect of pretreatment with progesterone on the oestrous response to oestradiol- $17 \beta$ benzoate in the postpartum dairy cow. Proc. N.Z. Soc. Anim. Prod. 52:157-160.

Mialot, J. P., G. Laummonnier, C. Ponsart, H. Fauxpoint, E. Barassin, A. A. Ponter, and F. Deletang. 1999. Postpartum subestrus in dairy cows: Comparison of treatment with prostaglandin $\mathrm{F}_{2 \alpha}$ or $\mathrm{GnRH}+$ prostaglandin $\mathrm{F}_{2 \alpha}+\mathrm{GnRH}$. Theriogenology 52:901-911. 
NRC. 1989. Nutrient Requirements of Dairy Cattle. 5th rev. ed. Natl. Acad. Sci. Washington, DC.

Orihuela, A. 2000. Some factors affecting the behavioural manifestation of oestrus in cattle: A review. Appl. Anim. Behav. Sci. 70:1-16.

Plunkett, S. S., J. S. Stevenson, and E. P. Call. 1984. Prostaglandin $\mathrm{F}_{2 \alpha}$ for lactating dairy cows with a palpable corpus luteum but unobserved estrus. J. Dairy Sci. 67:380-387.

Pursley, J. R., M. R. Kosorok, and M. C. Wiltbank. 1997. Reproductive management of lactating dairy cows using synchronization of ovulation. J. Dairy Sci. 80:301-306.

Reist, M., D. K. Erdin, D. von Euw, K. M. Tschümperlin, H. Leuenberger, H. M. Hammon, C. Morel, C. Philipona, Y. Zbinden, N. Künzi, and J. W. Blum. 2003. Postpartum reproductive function: Association with energy, metabolic and endocrine status in high yielding dairy cows. Theriogenology 59:1707-1723.

Rhoads, M. L., R. P. Rhoads, R. O. Gilbert, R. Toole, and W. R. Butler. 2006. Detrimental effects of high plasma urea nitrogen levels on viability of embryos from lactating dairy cows . Anim. Reprod. Sci. $91: 1-10$

Rhodes, F. M., S. McDougall, C. R. Burke, G. A. Verkerk, and K. L. Macmillan. 2003. Treatment of cow with extended postpartum anestrous interval. J. Dairy Sci. 86:1876-1894.

Sevinc, M., A. Bapoulu, H. G. Zelbektap, and M. Boydak. 2003. Lipid and lipoprotein levels in dairy cows with fatty liver. Turk. J. Vet. Anim. Sci. 27:295-299.

Silva, E., R. A. Sterry, and P. M. Fricke. 2007. Assessment of a practical method for identifying anovular dairy cows synchronized for first postpartum timed artificial insemination. J. Dairy Sci. 90:3255-3262

Smith, S. T., W. R. Ward, and H. Dobson. 1998. Use of ultrasonography to help to predict observed oestrus in dairy cows after the administration of prostaglandin $\mathrm{F}_{2 \alpha}$. Vet. Rec. 142:271-274.

Sommer, H. 1975. Preventive medicine in dairy cows. Vet. Med. Rev. $1 / 2: 42-63$
Spicer, L. J., J. Alonso, and C. S. Chamberlin. 2001. Effects of thyroid hormones on bovine granulosa and thecal cells function in vitro: Dependence on insulin and gonadotropins. J. Dairy Sci. 84:1069-1076.

Sterry, R. A., E. Silva, D. Kolb, and P. M. Fricke. 2009. Strategic treatment of anovular dairy cows with GnRH. Theriogenology 71:534-542.

Sterry, R. A., M. L. Welle, and P. M. Fricke. 2006. Treatment with GnRH after first timed artificial insemination improves fertility in noncycling lactating dairy cows. J. Dairy Sci. 89:4237-4245.

Stevenson, J. S., G. C. Lamb, D. P. Hoffman, and J. E. Minton. 1997. Inter-relationships of lactation and postpartum anovulation in suckled and milked cows. Livest. Prod. Sci. 50:57-84.

Vasconcelos, J. L. M., R. W. Silcox, and G. J. Rosa. 1999. Synchronization rate, size of the ovulatory follicle and pregnancy rate after synchronization of ovulation beginning on different days of the estrous cycle in lactating dairy cows. Theriogenology 52:1067-1078.

Whittier, W. D., F. C. Gwazdauskas, and M. L. McGilliard. 1989 Prostaglandin $\mathrm{F}_{2 \alpha}$ usage in a dairy reproduction program for treatment of unobserved estrus, pyometra and ovarian luteal cysts. Theriogenology 32:693-704.

Wildman, E. E., G. M. Jones, P. E. Wagner, R. L. Boman, H. F. Troutt, and T. N. Lesch. 1982. A dairy cow body condition scoring system and its relationship to selected production characteristics. J. Dairy Sci. 65:495-501.

Wiltbank, M. C., A. Gümen, and R. Sartori. 2002. Physiological classification of anovulatory conditions in cattle. Theriogenology $57: 21-52$.

Xu, Z. Z., L. J. Burton, and K. L. Macmillan. 1997. Reproductive performance of lactating dairy cows following estrus synchronization regimens with $\mathrm{PGF}_{2 \alpha}$ and progesterone. Theriogenology $47: 687-701$ 